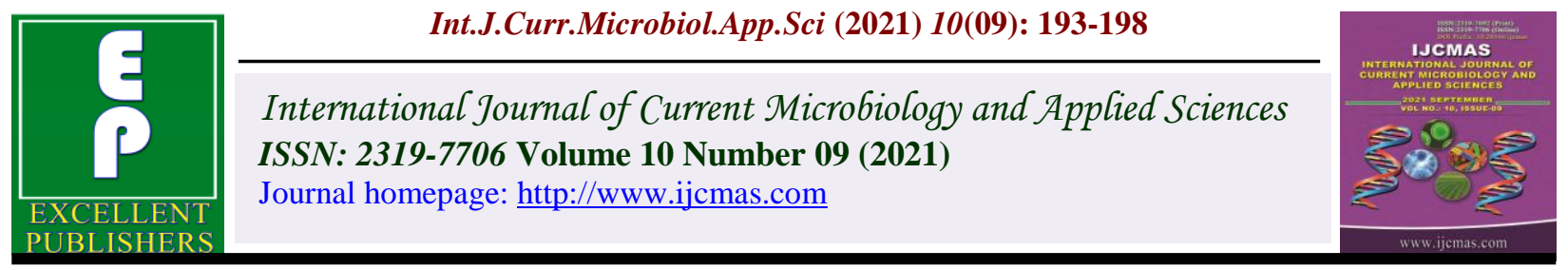

Original Research Article

https://doi.org/10.20546/ijcmas.2021.1009.022

\title{
Anthropometric and Nutritional Status of Adolescent Students in Bihar
}

\author{
Swiny Sandhvi ${ }^{*}$ and Mukul Sinha ${ }^{2}$ \\ ${ }^{1}$ Department of Food Science and Nutrition, College of Community and Applied Sciences, \\ MPUAT, Udaipur, India \\ ${ }^{2}$ Department of Food and Nutrition, College of Community Science, Dr. Rajendra Prasad \\ Central Agricultural University, Pusa, Samastipur, Bihar-848125, India \\ *Corresponding author
}

Keywords

Anthropometry, Nutrient intake, Adolescent, School students

Article Info

Accepted:

12 August 2021

Available Online:

10 September 2021

\section{A B S T R A C T}

Anthropometrics can be a sensitive indicator of health, growth and development in infants and children. Measurement of height, weight and nutrient intake are the reliable means to evaluate the nutritional status and it is very much in need. Nutritional status of a sample of 120 adolescent respondents, from Samastipur, district of Bihar were evaluated by anthropometric measurement \& nutrient intake. The correlation coefficient between protein and government school adolescent weight $(\mathrm{r}=0.280)$ was significantly positive but height and BMI was not significant. The correlation coefficient between protein and private school adolescent weight $(\mathrm{r}=0.542)$ and BMI ( $r=0.500)$ was positively correlated and highly significant while height was not significant. The correlation coefficient of iron with height, weight and BMI of government school adolescent was not significant. But in private school correlation coefficient of iron with weight $(\mathrm{r}=0.448)$ and $\mathrm{BMI}(\mathrm{r}=0.421)$ was positive and highly significant. Therefore this study suggests that the Anthropometric assessment and nutritional intake of adolescent students in Bihar should further be done for coming to a conclusion.

\section{Introduction}

Adolescence is a unique dynamic period in life, since it is the second and last growth spurt in the life of human beings. Anthropometric measurements can be used to track changes in teenage growth. An important factor of a country's health is research on anthropometric measures of teenagers. Height, weight, and nutrient intake measurements are the most reliable ways to assess nutritional status, and they are desperately needed. Adolescence is one of the most nutritionally stressful times of life, with increased demands for energy, protein, minerals, and vitamins (Gopalan et al., 2001). During this time, physical changes 
affect the body's nutritional needs, while changes in one's lifestyle may affect eating habits and food choices. Moreover nutritional health during adolescence is important for supporting the growing body and for preventing future health problems. Developing healthy eating habits as an adolescent can help grow and develop into a strong, healthy adult. Though, the health issues of adolescents like sexually transmitted diseases and reproductive health have been given due importance, limited research work has been done on their nutritional status, particularly from rural India (WHO 1995; Bose and Mukhopadhyay et al., 2005, Gaiki and Wagh 2014). Poor nutrition can lead to eating disorders, obesity, delayed sexual maturation and delay in reaching your full height potential. Hence the present study was undertaken to conduct the anthropometric assessment and to know the nutrient intake among adolescent school students in Pusa block of Samastipur district.

\section{Materials and Methods}

Two private and Two Government Schools of Samastipur district of Bihar were selected. A sample of 120 adolescent students (60 each from private and government schools) aged between 13 to16 years were selected by purposive sampling method. General information regarding caste, religion, family size, and types of family as well as their socioeconomic status was obtained from each subject.

The anthropometric measurements like height was measured while the subject was standing without foot wear, to the nearest $0.1 \mathrm{~cm}$, using a portable Anthropometry rod \& weight was measured with the subject standing and wearing light clothes to the nearest $0.1 \mathrm{~kg}$ using a portable electronic weighing machine. The Body Mass Index (BMI) is a widely used metric that has a moderate relationship with height in teenagers. The formula weight $(\mathrm{Kg})$ / height $\left(\mathrm{m}^{2}\right)$ was used to calculate Body Mass Index (BMI). Different parameters used for assessing their nutritional status were 24 hour dietary recall survey and anthropometric measurements. Intake of nutrient was computed using the values given in the nutritive value of Indian foods (Gopalan et al., 2001).

For anthropometric assessment \& nutrient intake questionnaire was developed. Direct interview method was adopted to collect relevant information from the respondent. The data have been presented in mean, SD and Correlation Coefficient.

General information about the subjects have been presented in Table 1. This table inferred that majority of the adolescent i.e., 41.6 percent and 38.4 percent from government and private school were of the age of 14 years followed by 33.4 percent and 26.6 percent of 15 years age group.

The table 1 further showed that 20 and 30 percent of adolescent from government and private school were of 13 years and 5 percent each were of 16 years. Table 1 also depicts that 50 percent of adolescents from both the government and private school were studying in VIII $^{\text {th }}$ and IX $^{\text {th }}$ class.

Table 1 further revealed that majority of the adolescents i.e., 63.3 percent from government school and 66.6 percent from private school were non-vegetarian followed by 16.6 percent and 30 percent lacto-vegetarian. The vegetarian from government school constitute 18.3 percent and from private school 1.6 percent. The Ovo-vegetarian from government and private school constitute 1.6 percent, each.

\section{Types and size of family of Subjects}

It is evident from the Table 1 that majority of the students i.e., 65 percent belonged to 
nuclear family followed by 26.6 percent of joint family and 8.3 percent of extended family. In private school, majority of the students belonged to nuclear family i.e., 53.3 percent followed by 36.6 percent of joint family and 10 percent of extended family.

The maximum percentage of students in both the schools belonged to nuclear family followed by joint and extended. Though the large family size (>10 members/family) was least ( $1.6 \& 3.3 \%$ respectively).

\section{Results and Discussion}

\section{Height}

Table 2 inferred that 53.3 percent of subjects both from government and private school falls in the category of $(152-158) \mathrm{cm}$, followed by 43.3 percent subjects from government school and 46 percent subjects from private school in the region of (145-151) $\mathrm{cm}$ and 1.6 percent subjects from government school falls in the region of (159-165) $\mathrm{cm}$ and (133-145) $\mathrm{cm}$.

Table 2 inferred that the height of government school adolescent were less compared to the height of private school subjects. This may be attributed due to the fact that government school subjects have poor nutritional intake than the private school subjects.

\section{Weight}

In relation to weight 35 and 36.6 percent of subjects from government and private school fall in between (30-40) $\mathrm{kg}$, followed by $60 \&$ 55 percent of the subjects from government and private school in the range of (40-50) $\mathrm{kg}$ and $5 \& 8.3$ percent of subjects from government and private school fell in between (50-60) $\mathrm{kg}$. The weight of both government and private school adolescent were approximately same.

\section{BMI}

BMI is the parameter to denote a person of ideal weight, over weight and obese. It was observed from the table that 61.6 and 48.3 percent of subjects from government and private school were having BMI 18-<21,28.3 and 33.3 percent of subjects from government and private school were in the range of $15-<18$ and 10 and 18.3 percent of subjects from government and private school were in the range of $21-<24$. This inferred that the private school adolescent had lower BMI compared to the government school adolescent.

Table 3 represents the Nutrients intake of subjects between government \& private school

\section{Energy (Kcal)}

As compared to R.D.A value of energy ( $2302 \mathrm{kcal})$, the calorie intake by the subjects of government school were (1571.47 \pm 235.71 Kcal) and private school subjects were (1605.45 $\pm 227.57 \mathrm{kcal})$.

\section{Protein (g)}

As compared to R.D.A value of energy (69g), the protein intake by the subjects of the government school was $(43.55 \pm 7.99 \mathrm{~g})$ and by private school was $(45.17 \pm 9.8 \mathrm{~g})$.

\section{Fat (g)}

As compared to R.D.A value of fat $(22 \mathrm{~g})$, the fat intake by the subjects of the government school was $(42.39 \pm 12.5 \mathrm{~g})$ and private school was $(46.79 \pm 10.16 \mathrm{~g})$.

\section{Iron (mg)}

As compared to R.D.A value of iron $(37 \mathrm{mg})$, the iron intake by the subjects of the government school was $(28.9 \pm 9.51 \mathrm{mg})$ and private school was $(30.40 \pm 6.94 \mathrm{mg})$. 
Table.1 General information of the subjects

\begin{tabular}{|c|c|c|c|c|}
\hline \multirow[t]{2}{*}{ Particulars } & \multicolumn{2}{|c|}{ Government school students (60) } & \multicolumn{2}{|c|}{ Private school students (60) } \\
\hline & \multirow[t]{2}{*}{ Frequency } & \multirow[t]{2}{*}{ Percentage } & \multirow[t]{2}{*}{ Frequency } & \multirow[t]{2}{*}{ Percentage } \\
\hline Age(years) & & & & \\
\hline 13 & 12 & 20 & 18 & 30 \\
\hline 14 & 25 & 41.6 & 23 & 38.4 \\
\hline 15 & 20 & 33.4 & 16 & 26.6 \\
\hline 16 & 3 & 5.0 & 3 & 5.0 \\
\hline Education & & & & \\
\hline $8^{\text {th }}$ & 30 & 50 & 30 & 50 \\
\hline $9^{\text {th }}$ & 30 & 50 & 30 & 50 \\
\hline Food habits & & & & \\
\hline Vegetarian & 11 & 18.3 & 1 & 1.6 \\
\hline Non-vegetarian & 38 & 63.3 & 40 & 66.6 \\
\hline Ovo-vegetarian & 1 & 1.6 & 1 & 1.6 \\
\hline Lacto-vegetarian & 10 & 16.6 & 18 & 30 \\
\hline A.Types of family & & & & \\
\hline Nuclear & 39 & 65 & 32 & 53.3 \\
\hline Joint & 16 & 26.6 & 22 & 36.6 \\
\hline Extended & 5 & 8.3 & 6 & 10 \\
\hline B.Family size & & & & \\
\hline $1-4$ & 12 & 20 & 17 & 28.3 \\
\hline $5-7$ & 38 & 63.3 & 32 & 53.3 \\
\hline$>7<10$ & 9 & 15 & 9 & 15 \\
\hline $10 \&>$ & 1 & 1.6 & 2 & 3.3 \\
\hline
\end{tabular}

Table.2 Anthropometric measurements of subjects

\begin{tabular}{|c|c|c|c|c|c|}
\hline \multirow{2}{*}{\multicolumn{2}{|c|}{ Particular }} & \multicolumn{2}{|c|}{ Government school students (60) } & \multicolumn{2}{|c|}{ Private school students (60) } \\
\hline & & Frequency & Percentage & Frequency & Percentage \\
\hline \multicolumn{6}{|c|}{ Height $(\mathbf{c m})$} \\
\hline & 133-145 & 1 & 1.6 & - & - \\
\hline & 145-151 & 26 & 43.3 & 28 & 46 \\
\hline & $152-158$ & 32 & 53.3 & 32 & 53.3 \\
\hline & $159-165$ & 1 & 1.6 & - & - \\
\hline \multicolumn{6}{|c|}{ Weight(kg) } \\
\hline & $30-40$ & 21 & 35 & 22 & 36.6 \\
\hline & $40-50$ & 36 & 60 & 33 & 55 \\
\hline & $50-60$ & 3 & 5 & 5 & 8.3 \\
\hline \multicolumn{6}{|c|}{ BMI $\left(\mathrm{kg} / \mathrm{m}^{2}\right)$} \\
\hline & $15-<18$ & 17 & 28.3 & 20 & 33.3 \\
\hline & $18-<21$ & 37 & 61.6 & 29 & 48.3 \\
\hline & $21-<24$ & 6 & 10 & 11 & 18.3 \\
\hline
\end{tabular}


Table.3 Nutrient intake by Subjects

\begin{tabular}{|c|c|c|c|}
\hline Particulars & Government school (60) & Private school(60) & \\
\hline & Mean \pm SD & Mean \pm SD & RDA $^{*}$ (ICMR) \\
\hline Energy(kcal) & $1571.47 \pm 235.71$ & $1605.45 \pm 227.57$ & 2302 \\
\hline Protein(gm) & $43.5 \pm 7.99$ & $45.17 \pm 9.8$ & 69 \\
\hline Fat(gm) & $42.39 \pm 12.5$ & $46.79 \pm 10.16$ & 22 \\
\hline Iron $(\mathbf{m g})$ & $28.9 \pm 9.51$ & $30.40 \pm 6.94$ & 37 \\
\hline Calcium $(\mathbf{m g})$ & $340.72 \pm 116.13$ & $369.04 \pm 112.68$ & 550 \\
\hline
\end{tabular}

* Recommended Dietary Allowances (ICMR, Gopalan et al., 1989)

Table.4 Correlation Coefficient between nutrient intake and anthropometric parameters.

\begin{tabular}{|c|c|c|c|c|c|c|}
\hline & \multicolumn{3}{|c|}{ Government } & \multicolumn{3}{c|}{ Private } \\
\hline & Height & Weight & BMI & Height & Weight & BMI \\
\hline Energy(Kcal) & -0.071 & $0.280^{*}$ & $0.380^{* *}$ & 0.143 & $0.368^{* *}$ & $0.333^{* *}$ \\
\hline Protein(g) & 0.178 & $0.297^{*}$ & 0.251 & 0.173 & $0.542^{* *}$ & $0.500^{* *}$ \\
\hline Fat(g) & -0.032 & 0.251 & $0.311^{*}$ & 0.108 & 0.059 & 0.008 \\
\hline Iron(mg) & 0.150 & 0.144 & 0.111 & 0.161 & $0.448^{* *}$ & $0.421^{* *}$ \\
\hline Calcium(mg) & 0.226 & $0.420^{* *}$ & $0.332^{* *}$ & 0.062 & $0.324^{*}$ & $0.301^{*}$ \\
\hline
\end{tabular}

*. Correlation is significant at the 0.05 level.

**. Correlation is significant at the 0.01 level.

\section{Calcium (mg)}

As compared to R.D.A value of calcium (550mg), the calcium intake by subjects of the government school was $(340.72 \pm 116.13 \mathrm{mg})$ and private school was $(369.04 \pm 112.68 \mathrm{mg})$.

\section{Correlation Coefficient between nutrient intake and anthropometric parameters}

In both the govt. and private school student's case weight \& BMI was positively correlated with their energy and protein intake but height had no significant relation with energy intake.

However the BMI was only significantly correlated to the fat intake of government School students and with height, weight and BMI of private school adolescents.

In case of nutrients like iron and calcium intake was positively correlated to weight and BMI of private school adolescents but in case of government school adolescent only weight and BMI were significantly correlated with the Calcium intake.

The findings were supported by Kumari M. R. et al., (2014), Goyal R. and Julka S. (2014), Miah S. et al., (2014), Odo F. I. et al., (2015).

The government school adolescent must have eaten more green leafy vegetable, cereals and pulses than private school adolescents, because of their economic condition but as the family income increases, the tendency towards eating green leafy vegetable by the adolescent specially decreases \& other costly items increases, including junk foods.

The low values of anthropometry obtained from this study suggested that there is need for improvement in the nutritional status of these adolescents. Besides, more attention needs to be done to address the issue of adolescent's health. 


\section{References}

Goyal, Raksha and Sandeep, Julka. (2014). Impact of breakfast skipping on the health states of the population. Indian J. Endocr Metab.Vol.18(5):683.

Gopalan, C., Ramasastri, B. V., and Balasubramanian, S. C. (1989). Nutritive Value of Indian Foods. National Institute of Nutrition, ICMR, Hyderabad, India.

Gopalan C, Sastri B P, Balasubramanian S C 2001. Nutritive Value of Indian Foods. Hyderabad: National Institute of Nutrition (ICMR).

Kumari, M. Rathnayake., Tharrmini, Roopasingam., and Ramasighe, V. P. Wick. (2014). Nutritional and Behaviour Determinants of Adolescent obesity : A case-control study in Srilanka. Health Behaviour, Health Promotion and Society. Vol.14(14):1291.

Gaiki V, Wagh V 2014. Nutritional status of adolescent girls from selected rural areas of a district from Central India. Innovative Journal of Medicine and Health Science, 4(2): 90-92.

Gupta M K, Mohapatra A, Shivalli S, Mishra
C P 2011.Nutritional estimates of school going children based on anthropometric measurements: Study from a rural area of Varanasi. Indian Journal of Community Health, 23(2): 38-39.

Miah, Sharmim., Md., Rahman, Nannur. M., Prodhan, U. K., Madumita, Linkon. M. R., and Rahman, Sindur. Md. (2014). Prevalence of iron deficiency anemia among adolescent girls and its risk factors in Tangail region Bangladesh. International journal of research in engineering and technology. Vol.3:eISSN:2319-1163/pISSN:23217308.

Mukhopadhya A, Bhadra M, Bose K 2005. Anthropometric assessment of nutritional status of adolescent in Kolkata, West Bengal. J Hum Ecol, 18(3): 213-216.

Odo, F. Ifeoma., Lawrence, U. S. Ezeayika., and Nene, Uchendu.(2015). The relationship among body composition and body mass index in a population of adolescents in Enugu State, Nigeria. Int.J.Curr.Microbiol.app.Sci. Vol.4(1): 884-897.ISSN:2319-7706.

\section{How to cite this article:}

Swiny Sandhvi and Mukul Sinha. 2021. Anthropometric and Nutritional Status of Adolescent Students in Bihar. Int.J.Curr.Microbiol.App.Sci. 10(09): 193-198. doi: https://doi.org/10.20546/ijcmas.2021.1009.022 